\title{
Isolated Adrenocorticotropin Deficiency Concomitant with Graves' Disease: A Case Report and Literature Review
}

\author{
Nobumasa Ohara ${ }^{1,2}$, Masanori Kaneko ${ }^{1}$, Hideyuki Kuriyama ${ }^{3}$, Kazuhiro Sato ${ }^{3}$, \\ Hideki Katakami ${ }^{4}$, Yutaka Oki ${ }^{5}$, Kenzo Kaneko ${ }^{1}$ and Kyuzi Kamoi ${ }^{6,7}$
}

\begin{abstract}
A 73-year-old Japanese woman with untreated Graves' hyperthyroidism developed glucocorticoid-induced adrenal insufficiency (AI) after a supraphysiological dose of prednisolone therapy for bronchial asthma. Days later, she had high plasma adrenocorticotropic hormone (ACTH) levels and was expected to recover from glucocorticoid-induced AI. Her plasma ACTH levels remained high over 3 months during a physiological dose of hydrocortisone replacement. However, she suffered a further decrease in her serum cortisol level and was diagnosed with isolated adrenocorticotropin deficiency (IAD), in which bioinactive ACTH likely caused the high ACTH value. IAD should be considered as an unusual disorder associated with Graves' disease, especially in older patients.
\end{abstract}

Key words: isolated adrenocorticotropin deficiency, glucocorticoid-induced adrenal insufficiency, Graves' disease, bronchial asthma, type 2 diabetes mellitus, empty sella turcica

(Intern Med 55: 2649-2658, 2016)

(DOI: 10.2169/internalmedicine.55.6599)

\section{Introduction}

Adrenocorticotropic hormone (ACTH), a 39-amino-acid bioactive peptide, is derived from anterior pituitary corticotroph cells after enzymatic post-translational modifications of the 241-amino-acid preproprotein, proopiomelanocortin (POMC) $(1,2)$. The major factor stimulating ACTH release is corticotropin-releasing hormone $(\mathrm{CRH})$ that is secreted from the hypothalamus.

Adrenal insufficiency (AI) is a potentially life-threatening disorder resulting from glucocorticoid deficiency, with or without loss of mineralocorticoids or adrenal androgens (3). Clinical manifestations of AI include nonspecific symptoms such as fatigue, lethargy, anorexia, and hypoglycemia. According to the underlying mechanism, AI can be classified as primary (Addison's disease), secondary, or tertiary.

Glucocorticoid-induced AI is the most common form of tertiary AI and results from suppression of both hypothalamic CRH and pituitary ACTH by supraphysiological doses of exogenous glucocorticoids (4). Spontaneous recovery typically occurs during the administration of physiological doses of corticosteroid replacement, such as oral hydrocortisone at daily doses of $\leq 20 \mathrm{mg}(3-5)$. Patients with glucocorticoid-induced AI have low plasma ACTH levels, however, they may exhibit transiently high plasma ACTH levels during the recovery phase (6).

Secondary AI results from pituitary disease that hampers the release of ACTH (3), and patients usually have low plasma ACTH levels. However, there are reported cases of secondary AI in which bioinactive ACTH, which produce a high measured plasma ACTH value, are present (7-9). Some of these are high molecular weight peptides, such as pro$\mathrm{ACTH}$ and POMC, which are also referred to as "big ACTH" (10, 11).

Isolated adrenocorticotropin deficiency (IAD) is a rare,

\footnotetext{
${ }^{1}$ Department of Endocrinology and Metabolism, Nagaoka Red Cross Hospital, Japan, ${ }^{2}$ Department of Endocrinology and Metabolism, Uonuma Institute of Community Medicine, Niigata University Medical and Dental Hospital, Japan, ${ }^{3}$ Department of Respiratory Medicine, Nagaoka Red Cross Hospital, Japan, ${ }^{4}$ Division of Clinical Research Sciences, Department of Medicine, Teikyo University Chiba Medical Center, Japan, ${ }^{5}$ Department of Family and Community Medicine, Hamamatsu University School of Medicine, Japan, ${ }^{6}$ Department of Internal Medicine, Ojiya General Hospital, Japan and ${ }^{7}$ Center of Diabetes, Endocrinology and Metabolism, Joetsu General Hospital, Japan

Received for publication September 21, 2015; Accepted for publication January 5, 2016

Correspondence to Dr. Nobumasa Ohara, oharan@med.niigata-u.ac.jp
} 
heterogeneous pituitary disease characterized by secondary AI with normal secretion of pituitary hormones other than ACTH (12). Patients with IAD often have organ-specific autoimmune disorders, such as Hashimoto's thyroiditis (13). A few cases of IAD associated with Graves' disease have also been reported (14-17).

We herein report the case of an elderly patient with Graves' disease who developed IAD in association with glucocorticoid-induced AI; she expressed a form of bioinactive ACTH that differed from "big ACTH." In addition, previously reported cases of concomitant IAD and Graves' disease are reviewed.

\section{Measurement of adrenocorticotropic hormone in the plasma}

All measurements of plasma ACTH in the clinical setting were performed using a two-site electro-chemiluminescence immunoassay (ECLIA) (Roche Diagnostics, Tokyo, Japan) (18). This assay employs a monoclonal antibody against the N-terminal fragment 9-12 and a monoclonal antibody against the C-terminal fragment 36-39 of ACTH (19).

The basal ACTH levels in plasma samples collected in March and August 2013, and February 2015, were also measured using an immunoradiometric assay (IRMA) (LSI Medience, Tokyo, Japan) (20), a fluorescence enzyme immunoassay (FEIA) (Tosoh, Tokyo, Japan) $(19,21)$, and an immune complex transfer enzyme immunoassay (ICT-EIA) I $(19,22)$.

\section{Measurement of $\gamma 3-$ melanocyte-stimulating hormone levels in the plasma}

To quantitatively assess "big ACTH" levels in the plasma, we measured the $\gamma 3$-melanocyte-stimulating hormone (MSH) levels. This assay does not detect the authentic ACTH 1-39 peptide but sensitively detects both POMC and POMCderived peptides, including pro-ACTH $(19,23)$.

\section{Analysis of the molecular size of adrenocortico- tropic hormone in the plasma}

The molecular size of ACTH in the patient's plasma was analyzed using gel exclusion chromatography. The fractionating procedure for the measurement of ACTH with a radioimmunoassay (RIA) was performed as described previously (24). A non-extracted plasma sample $(0.5 \mathrm{~mL})$ was applied to Sephadex G75 $(1 \times 50 \mathrm{~cm})$ gel chromatography; the ACTH concentration was determined by a specific conventional RIA. The ACTH RIA uses a rabbit polyclonal antiserum against the N-terminal fragment 1-24 of ACTH. The anti-serum of the RIA system identifies ACTH 1-24containing peptides equally, including ACTH 1-24, ACTH 139, pro-ACTH, and POMC.

\section{Case Report}

A 73-year-old Japanese woman presented at our hospital in mid-February 2013 due to a 4-month history of fatigue, exertional dyspnea, and anorexia. She had a maternal family history of cerebral infarction. The patient gave birth twice in her twenties and had no history of obesity, head trauma, or pituitary disease. The patient had been treated with theophylline and antihypertensive drugs for bronchial asthma and essential hypertension, respectively, since 30 years of age. She was diagnosed with type 2 diabetes mellitus at 68 years of age, for which she followed dietary therapy comprising 1,400 kcal/day, and her HbA1c (National Glycohemoglobin Standardization Program, NGSP) (25) level was approximately $6 \%$. Around the same time, she started inhaled corticosteroid therapy with ciclesonide at $200 \mu \mathrm{g} /$ day for her bronchial asthma, which was well controlled without additional systemic corticosteroids. The patient developed fatigue, lethargy, and appetite loss in October 2012, and her body weight decreased from $40 \mathrm{~kg}$ to $29 \mathrm{~kg}$ within 1 month. She visited her primary care physician in February 2013 after experiencing wheezing and exertional dyspnea for a few days. She received a regimen of oral prednisolone therapy (3 days of $10 \mathrm{mg} /$ day and 5 days of $5 \mathrm{mg} /$ day) for exacerbation of her bronchial asthma. On day 8 of the corticosteroid regimen, the patient was transferred to our hospital for a detailed examination of her persisting fatigue, lethargy, and anorexia.

On this physical examination, the patient was $148 \mathrm{~cm}$ tall and weighed $29 \mathrm{~kg}$ (body mass index, $13.2 \mathrm{~kg} / \mathrm{m}^{2}$ ). Her consciousness was clear, and her body temperature, blood pressure, and pulse rate were $36.9^{\circ} \mathrm{C}, 126 / 45 \mathrm{mmHg}$, and 99 beats per minute, respectively. She presented with no headache, visual or vision disturbance, cough, or wheezing. No heart murmurs or chest rales were detected. There was no exophthalmos or skin pigmentation, however, she had mild struma without pain, moist skin, and bilateral finger tremor. Laboratory data showed primary hyperthyroidism [thyroidstimulating hormone $(\mathrm{TSH}),<0.01 \mu \mathrm{U} / \mathrm{mL}$; free triiodothyronine $\left(\mathrm{FT}_{3}\right), 18.2 \mathrm{pg} / \mathrm{mL}$; and free thyroxine $\left(\mathrm{FT}_{4}\right),>8.0 \mathrm{ng} /$ dL]. Ultrasonography showed a diffusely enlarged thyroid gland and a technetium-99m thyroid scintigraphy showed diffusely elevated uptake in the goiter. According to these findings, the patient was diagnosed with Graves' disease (26) and thus was started an oral antithyroid drug treatment with thiamazole ( $15 \mathrm{mg} /$ day).

The next day, she was taken by ambulance to our hospital because she had fallen into a coma. Her body temperature, blood pressure, and pulse rate were $36.5^{\circ} \mathrm{C}, 133 / 40 \mathrm{mmHg}$, and 79 beats per minute, respectively, and her blood chemistry (Table 1) revealed hypoglycemia. The serum levels of immunoreactive insulin and C-peptide were appropriately inhibited, and counterregulatory hormones, such as growth hormone and catecholamines, responded appropriately. However, her serum cortisol and plasma ACTH levels were relatively decreased. After recovery from hypoglycemia upon continuous intravenous glucose infusion, the patient recovered consciousness and was admitted for further endocrine examinations.

The patient was considered to have glucocorticoid- 
Table 1. Laboratory Findings from the Emergency Room Visit (at 3:00 PM) after Transportation to Our Hospital in February 2013.

\begin{tabular}{|c|c|c|}
\hline \multicolumn{3}{|l|}{ Hematology } \\
\hline Red blood cells & $421 \times 10^{4} / \mu \mathrm{L}$ & $(427-571)$ \\
\hline Hemoglobin & $11.8 \mathrm{~g} / \mathrm{dL}$ & $(12.4-17.2)$ \\
\hline Hematocrit & $35.9 \%$ & $(38.7-50.3)$ \\
\hline White blood cells & $7,700 / \mu \mathrm{L}$ & $(4,000-9,000)$ \\
\hline Platelets & $14.8 \times 10^{4} / \mu \mathrm{L}$ & $(12.0-30.0)$ \\
\hline \multicolumn{3}{|l|}{ Chemistry } \\
\hline Casual plasma glucose & $0.78 \mathrm{mmol} / \mathrm{L}$ & $(3.9-7.8)$ \\
\hline Serum immunoreactive insulin & $<0.5 \mu \mathrm{U} / \mathrm{mL}$ & $(2.2-12.4)$ \\
\hline Serum C-peptide & $<0.2 \mathrm{ng} / \mathrm{mL}$ & $(1.1-3.3)$ \\
\hline HbAlc (NGSP) & $6.0 \%$ & $(4.6-6.2)$ \\
\hline Total protein & $7.3 \mathrm{~g} / \mathrm{dL}$ & $(6.7-8.3)$ \\
\hline Albumin & $3.9 \mathrm{~g} / \mathrm{dL}$ & $(3.8-5.3)$ \\
\hline Aspartate aminotransferase & $21 \mathrm{IU} / \mathrm{L}$ & $(13-33)$ \\
\hline Alanine aminotransferase & $16 \mathrm{IU} / \mathrm{L}$ & $(8-42)$ \\
\hline Urea nitrogen & $16.1 \mathrm{mg} / \mathrm{dL}$ & $(8.0-20.0)$ \\
\hline Creatinine & $0.41 \mathrm{mg} / \mathrm{dL}$ & $(0.60-1.00)$ \\
\hline Sodium & $140 \mathrm{mmol} / \mathrm{L}$ & $(137-147)$ \\
\hline Potassium & $4.5 \mathrm{mmol} / \mathrm{L}$ & $(3.5-4.7)$ \\
\hline Chloride & $101 \mathrm{mmol} / \mathrm{L}$ & $(98-108)$ \\
\hline C-reactive protein & $5.07 \mathrm{mg} / \mathrm{dL}$ & $(<0.30)$ \\
\hline Thyroid-stimulating hormone & $<0.01 \mu \mathrm{U} / \mathrm{mL}$ & $(0.30-4.30)$ \\
\hline Free triiodothyronine & $11.21 \mathrm{pg} / \mathrm{mL}$ & $(2.00-4.90)$ \\
\hline Free thyroxine & $>8.00 \mathrm{ng} / \mathrm{dL}$ & $(0.70-1.80)$ \\
\hline Growth hormone & $8.7 \mathrm{ng} / \mathrm{mL}$ & $(0-0.5)$ \\
\hline Insulin-like growth factor 1 & $107 \mathrm{ng} / \mathrm{mL}$ & $(38-207)$ \\
\hline Plasma ECLIA-ACTH & $58.9 \mathrm{pg} / \mathrm{mL}$ & $(7.2-63.3)$ \\
\hline Serum cortisol & $14.5 \mu \mathrm{g} / \mathrm{dL}$ & $(10.0-25.0)$ \\
\hline Serum DHEA-S & $225 \mathrm{ng} / \mathrm{mL}$ & $(70-1770)$ \\
\hline Plasma renin activity & $0.3 \mathrm{ng} / \mathrm{mL} / \mathrm{h}$ & $(0.1-2.0)$ \\
\hline Serum aldosterone & $5.6 \mathrm{ng} / \mathrm{dL}$ & $(3.0-15.9)$ \\
\hline Plasma noradrenalin & $1.73 \mathrm{ng} / \mathrm{mL}$ & $(0.06-0.46)$ \\
\hline Plasma adrenalin & $0.17 \mathrm{ng} / \mathrm{mL}$ & $(0-0.07)$ \\
\hline Plasma dopamine & $0.23 \mathrm{ng} / \mathrm{mL}$ & $(0-0.014)$ \\
\hline \multicolumn{3}{|c|}{$\begin{array}{l}\text { Blood samples were taken from the patient in a hypoglycemic coma. The } \\
\text { reference range for each parameter is shown in parentheses. } \\
\text { ACTH: adrenocorticotropic hormone, ECLIA: electro-chemiluminescence } \\
\text { immunoassay, DHEA-S: dehydroepiandrosterone sulfate, NGSP: National } \\
\text { Glycohemoglobin Standardization Program }\end{array}$} \\
\hline
\end{tabular}

induced $\mathrm{AI}$ and was prescribed $10 \mathrm{mg}$ oral hydrocortisone on the day of admission, with continuing oral hydrocortisone replacement at $5 \mathrm{mg} /$ day (5 $\mathrm{mg}$ in the morning) from the second morning, to recover her adrenal function; she continued oral thiamazole and inhaled ciclesonide (Fig. 1). Her fasting plasma glucose levels were maintained between 4.2 and $5.8 \mathrm{mmol} / \mathrm{L}$ after discontinuation of intravenous glucose infusion, and her systolic blood pressure and pulse rate were approximately $120 \mathrm{mmHg}$ and 80 beats per minute, respectively.

On day 4 of this admission, the patient had low basal serum cortisol and high plasma ACTH levels (Table 2A). She showed incomplete endogenous cortisol release after a single-dose administration of synthetic ACTH 1-24 (Table 2B). However, adequate cortisol release was observed during a prolonged synthetic ACTH 1-24 load (Table 2C). Dynamic tests for secretion of pituitary hormones showed no TSH response and normal release of growth hormone $(\mathrm{GH})$, prolactin, luteinizing hormone ( $\mathrm{LH})$, and folliclestimulating hormone (FSH). Although her plasma ACTH level, both before and after a CRH load or the administra- tion of growth hormone-releasing peptide (GHRP)-2, was high, no cortisol response was observed (Table 2D and E). These findings suggested diagnoses of either the recovery phase of glucocorticoid-induced AI, secondary AI accompanied by bioinactive ACTH, or the early phase of Addison's disease in the presence of primary hyperthyroidism due to Graves' disease. The patient continued oral thiamazole at 15 $\mathrm{mg} /$ day and oral hydrocortisone replacement at $10 \mathrm{mg} /$ day (5 $\mathrm{mg}$ in the morning and $5 \mathrm{mg}$ in the evening) (Fig. 1). Magnetic resonance imaging of the pituitary gland revealed an empty sella turcica (Fig. 2). Abdominal computed tomography detected no abnormalities in the adrenal glands, which did not contain a tumor or exhibit atrophy or calcification (Fig. 3). The patient tested negative for anti-pituitary cell antibody, thyroid peroxidase antibody (7 IU/mL; reference range, $<16 \mathrm{IU} / \mathrm{mL}$ ), thyroglobulin antibody $(12 \mathrm{IU} / \mathrm{mL}$; reference range, $<28 \mathrm{IU} / \mathrm{mL}$ ), and anti-adrenocortical antibody (titer $<1: 10$ ), but tested positive for both thyroidstimulating hormone receptor antibody (37.7 IU/L; reference range, <1.0 IU/L) and thyroid stimulating antibody (693\%; reference range, $<180 \%$ ). In addition, she tested negative for glutamic acid decarboxylase antibody $(<1.3 \mathrm{U} / \mathrm{mL})$, insulin antibody $(<125.0 \mathrm{nU} / \mathrm{mL})$, gastric parietal cell antibody (titer $<1: 10$ ), anti-nuclear antibody (titer $<1: 40$ ), and rheumatoid factor $(<5 \mathrm{IU} / \mathrm{mL})$. Human leukocyte antigen (HLA) typing showed the presence of $A * 02 / 26, B * 15 / 40$, and $C * 01: 02 / 08$ : 01 class I genes and DRB1*09:01/15:01, DQB1*03:03/06: 02, DQA1*01:02/03:02, and DPB1*02:01/05:01 class II genes.

To further explore the plasma ACTH level, ACTH in a plasma sample collected at $8 \mathrm{AM}$ on day 21 of admission (Table 2D) was assayed using IRMA, FEIA, and ICT-EIA I, all of which showed that the ACTH level was high (Table 3). In contrast, $\gamma 3$-MSH was undetectable (Table 2D, 3).

The size of ACTH was determined by gel exclusion chromatography of the plasma sample collected at 8 AM on day 21 of admission. The elution profile (Fig. 4) featured a single peak at approximately the authentic ACTH 1-39 position (fractions 28 to 30). "Big ACTH," which would appear at fraction numbers 14 to $20(8,9,24)$, was not observed.

The patient experienced improvements in fatigue and moist skin, and regained her previous vigor and appetite. She was discharged 27 days after admission, in March 2013. Two months later, the patient's plasma ACTH levels before and after a CRH load remained high, but she still exhibited cortisol deficiency (Table 2F) and continued hydrocortisone replacement.

In August 2013, her body weight returned to $40 \mathrm{~kg}$, her essential hypertension reappeared, and the patient restarted antihypertensive medication. Dynamic tests performed in a euthyroid state showed normal release of $\mathrm{GH}, \mathrm{TSH}$, prolactin, LH, and FSH. The patient's plasma ACTH levels increased above $90 \mathrm{pg} / \mathrm{mL}$ after a CRH load, however, no cortisol response was observed (Table 2G). Her basal serum dehydroepiandrosterone-surface (DHEA-S) level decreased, while her basal serum aldosterone level remained normal 


\begin{tabular}{|c|c|c|c|c|c|c|c|c|c|c|}
\hline & 012 & & & 2013 & & & & 14 & 201 & \\
\hline & Oct & Feb & Mar & May & Aug & Dec & Feb & Sept & Feb & \\
\hline $\begin{array}{l}\text { Inhaled } \\
\text { ciclesonide }\end{array}$ & 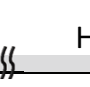 & lospita & $\overrightarrow{\text { alizatic }}$ & & 0.2 & $/$ day & & & & \\
\hline Oral thi & iamazo & le $15 r$ & $\mathrm{mg} / \mathrm{day}$ & & 7 & $\mathrm{mg} / \mathrm{da}$ & & $10 \mathrm{mg} / \mathrm{s}$ & & \\
\hline $\begin{array}{l}\text { Oral hydro } \\
\text { Intravenou }\end{array}$ & $\begin{array}{l}\text { cortiso } \\
\text { Is gluco }\end{array}$ & $\begin{array}{l}\text { ne } \\
\text { se }\end{array}$ & 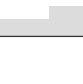 & & & $10 \mathrm{~m}$ & /day & & & \\
\hline $\begin{array}{r}\mathrm{O} \\
\text { predni }\end{array}$ & $\begin{array}{l}\text { ral } \\
\text { isolone }\end{array}$ & * & Oral a & mlodip & & & $5 \mathrm{mg}$ & /day & & \\
\hline Hypoglycemic a & attack - & $\rightarrow \Delta$ & & Ora & alogli & & & $25 \mathrm{mg} / \mathrm{d}$ & & \\
\hline $\begin{array}{l}\text { Wheezing } \\
\text { Appetite loss }\end{array}$ & & $\bigcap$ & & & & & & & & \\
\hline Body weight (kg) & 40 & 29 & & 37 & 40 & 41 & 41 & 41 & 40 & {$[40.5-54.8]$} \\
\hline $\mathrm{HbA1c}$ (NGSP)(\%) & 6.2 & 6.0 & 5.6 & 6.2 & 6.7 & 7.3 & 7.0 & 6.5 & 6.7 & {$[4.6-6.2]$} \\
\hline ACTH $(\mathrm{pg} / \mathrm{mL})$ & & 58.9 & 77.2 & 65.6 & 51.8 & & & & 31.6 & {$[7.2-63.3]$} \\
\hline Cortisol ( $\mu \mathrm{g} / \mathrm{dL})$ & & 14.5 & 7.1 & 6.1 & 3.6 & & & & 3.4 & {$[10.0-25.0]$} \\
\hline DHEA-S (ng/mL) & & 225 & 182 & 71 & 48 & & & & 55 & {$[70-1,770]$} \\
\hline PRA (ng/mL/h) & & 0.3 & & 1.1 & 1.2 & & & & 1.3 & {$[0.1-2.0]$} \\
\hline Aldosterone (ng/dL) & & 5.6 & & 12.5 & 12.7 & & & & 14.2 & [3.0-15.9] \\
\hline $\mathrm{TSH}(\mu \mathrm{U} / \mathrm{mL})$ & & $<0.01$ & $<0.01$ & 1.67 & 2.11 & 0.79 & 1.07 & 0.81 & 6.02 & {$[0.35-4.94]$} \\
\hline $\mathrm{FT}_{3}(\mathrm{pg} / \mathrm{mL})$ & & 11.2 & 1.84 & 2.19 & 2.01 & 2.43 & 2.27 & 2.28 & 2.46 & {$[1.71-3.71]$} \\
\hline $\mathrm{FT}_{4}(\mathrm{ng} / \mathrm{dL})$ & & $>8.00$ & 2.80 & 0.45 & 0.71 & 1.00 & 1.11 & 0.89 & 0.78 & {$[0.70-1.48]$} \\
\hline $\operatorname{TRAb}(\mathrm{IU} / \mathrm{L})$ & & 37.7 & 34.7 & 21.3 & 17.5 & 12.9 & 11.2 & 19.4 & 10.1 & {$[<1.0]$} \\
\hline
\end{tabular}

Figure 1. Clinical course. Reference ranges for body weight, HbA1c (NGSP), and plasma adrenocorticotropic hormone (ACTH) levels measured by an electro-chemiluminescence immunoassay (ECLIA), plasma renin activity (PRA), serum cortisol, dehydroepiandrosterone sulfate (DHEA-S), aldosterone, thyroid-stimulating hormone (TSH), free triiodothyronine $\left(\mathrm{FT}_{3}\right)$, free thyroxine (FT), and thyroid-stimulating hormone receptor antibody (TRAb) are shown in square brackets. All of the blood samples were taken at 8:00 AM with the patient in the supine position, except for those in February 2013, when the samples were taken at 3:00 PM with the patient in a hypoglycemic coma. The reference range for body weight $(\mathrm{kg})$ was calculated as follows: [body height $(\mathrm{m})^{2} \times 18.5$ ] to [body height $\left.(\mathrm{m})^{2} \times 25\right]$. * The patient received a regimen of 8 days of oral prednisolone $(10 \mathrm{mg} / \mathrm{day}$ for 3 days followed by $5 \mathrm{mg} /$ day for 5 days) for an exacerbation of her bronchial asthma.

(Fig. 1).

In December 2014, her HbA1c levels were elevated to above $7 \%$, and she started treatment with an oral hypoglycemic agent. In February 2015, dynamic tests performed in a subclinical primary hypothyroid state showed an excessive TSH response and normal release of GH, prolactin, LH, and FSH. Significant plasma ACTH release was observed after a $\mathrm{CRH}$ load, while no cortisol release was detected (Table $2 \mathrm{H}$ ). These serial changes in the patient's pituitary and adrenocortical hormone levels, including the fall in serum cortisol but continued aldosterone secretion during 2 years of hydrocortisone replacement (Fig. 1), were not consistent with Addison's disease or a recovery process from glucocorticoid-induced AI and rather indicated a diagnosis of IAD, in which biochemically measurable ACTH with low bioactivity that differed from "big ACTH" might have been present.

The patient continued treatment with hydrocortisone replacement and antithyroid drugs, and her subsequent clinical course has remained uneventful without any additional complications.

\section{Discussion}

An elderly Japanese woman with a 4-month history of fatigue, exertional dyspnea, lethargy, and anorexia was diagnosed with thyrotoxicosis due to Graves' disease during 1week treatment with a supraphysiological dose $(5-10 \mathrm{mg}$ / day) of oral prednisolone for her exacerbated bronchial asthma, which had been treated with inhaled corticosteroid therapy with a physiological dose $(200 \mu \mathrm{g} /$ day $)$ of ciclesonide (27). The day after completing this corticosteroid regimen, she developed a hypoglycemic coma with mild glucocorticoid-induced AI (Table 1) and underwent intravenous glucose infusion with physiological doses of oral hydrocortisone (replacement therapy). A few days later, she had a low serum cortisol and a high plasma ACTH level (Table 2A). Because the patient was anticipated to recover from glucocorticoid-induced AI, she was continued on hydrocortisone replacement, and her plasma ACTH level remained elevated for $>3$ months. However, both her serum cortisol and DHEA-S (28) levels further decreased during that period (Fig. 1). In addition, 2 years later, her plasma ACTH levels before and after a CRH load appeared to be 
Table 2. Endocrinological Investigation.

A. Morning and midnight serum cortisol and plasma ACTH levels in February 2013 (day 4 after admission)

\begin{tabular}{|c|c|c|}
\hline & 8:00 AM & 12:00 PM \\
\hline Plasma ECLIA-ACTH (pg/mL) & 80.4 & 45.4 \\
\hline Serum cortisol $(\mu \mathrm{g} / \mathrm{dL})$ & 6.5 & 2.0 \\
\hline
\end{tabular}

B. Rapid ACTH stimulation test in February 2013 (day 7 after admission)

\begin{tabular}{lccc}
\hline & Before & $30 \mathrm{~min}$ & $60 \mathrm{~min}$ \\
\hline Serum cortisol $(\mu \mathrm{g} / \mathrm{dL})$ & 5.8 & 9.0 & 10.2 \\
Serum aldosterone $(\mathrm{ng} / \mathrm{dL})$ & 3.6 & 5.7 & 4.9 \\
Plasma ECLIA-ACTH $(\mathrm{pg} / \mathrm{mL})$ & 67.7 & 62.7 & 63.4 \\
\hline
\end{tabular}

Synthetic ACTH 1-24 (cosyntropin hydroxide $0.25 \mathrm{mg}$ ) was intravenously administered in the morning (8:00 AM). The test was conducted after cessation of hydrocortisone replacement therapy $(5$ $\mathrm{mg} /$ day) for a day.

C. Prolonged ACTH stimulation test in February 2013 (days 13 to 16 after admission)

\begin{tabular}{lccc}
\hline & Before & 3 days & Reference range \\
\hline Serum cortisol $(\mu \mathrm{g} / \mathrm{dL})$ & 5.0 & 26.3 & $(10.0-25.0)$ \\
Urinary free cortisol excretion $(\mu \mathrm{g} /$ day $)$ & 8.3 & 255.0 & $(11.2-80.3)$ \\
Serum aldosterone $(\mathrm{ng} / \mathrm{dL})$ & 5.0 & 5.4 & $(3.0-15.9)$ \\
Plasma renin activity $(\mathrm{ng} / \mathrm{mL} / \mathrm{h})$ & 1.0 & 0.2 & $(0.1-2.0)$ \\
Plasma ECLIA-ACTH $(\mathrm{pg} / \mathrm{mL})$ & 87.3 & 11.0 & $(7.2-63.3)$ \\
\hline
\end{tabular}

Blood and urine samples were taken each morning (8:00 AM) of the 2 days before and after intramuscular administration of synthetic ACTH 1-24 (cosyntropin zinc hydroxide $1.0 \mathrm{mg} /$ day) for 3 days. Hydrocortisone replacement therapy $(5 \mathrm{mg} /$ day) was briefly discontinued the day before and for the duration of test.

D. CRH/GRF/TRH/LHRH stimulation test in March 2013 (day 21 after admission)

\begin{tabular}{|c|c|c|c|c|c|c|}
\hline & \multicolumn{6}{|c|}{ Time $(\min )$} \\
\hline & 0 & 15 & 30 & 60 & 90 & 120 \\
\hline Plasma ECLIA-ACTH (pg/mL) & 77.2 & 78.5 & 88.3 & 94.4 & 100.6 & 88.3 \\
\hline Plasma $\gamma 3-\mathrm{MSH}(\mathrm{pg} / \mathrm{mL})$ & $<30.0$ & $<30.0$ & $<30.0$ & $<30.0$ & $<30.0$ & $<30.0$ \\
\hline Serum cortisol $(\mu \mathrm{g} / \mathrm{dL})$ & 7.1 & 7.1 & 6.7 & 7.2 & 7.5 & 7.1 \\
\hline Serum TSH $(\mu \mathrm{U} / \mathrm{mL})$ & $<0.01$ & $<0.01$ & $<0.01$ & $<0.01$ & $<0.01$ & $<0.01$ \\
\hline Serum GH (ng/mL) & 1.2 & 10.5 & 17.1 & 21.0 & 11.9 & 6.2 \\
\hline Serum prolactin $(\mathrm{ng} / \mathrm{mL})$ & 12.4 & 27.6 & 36.9 & 32.9 & 26.7 & 23.1 \\
\hline Serum LH $(\mathrm{mIU} / \mathrm{mL})$ & 10.4 & 16.2 & 22.6 & 27.0 & 29.8 & 29.6 \\
\hline Serum FSH (mIU/mL) & 31.8 & 33.8 & 37.1 & 36.8 & 39.9 & 41.3 \\
\hline
\end{tabular}

The following were intravenously administered in the morning (8:00 AM): CRH $100 \mu \mathrm{g}$, GRF $100 \mu \mathrm{g}$, TRH $500 \mu \mathrm{g}$, and LHRH 100 $\mu \mathrm{g}$. The test was conducted after cessation of hydrocortisone replacement therapy ( $5 \mathrm{mg} / \mathrm{day})$ for a day. The patient had a serum level of estradiol of $5.0 \mathrm{pg} / \mathrm{mL}$ (reference range, $<39.0 \mathrm{pg} / \mathrm{mL}$ ). As shown in Table 1, the patient had primary hyperthyroidism due to Graves' disease.

E. Data from the GHRP-2 stimulation test performed on March 2013 (day 24 after admission).

\begin{tabular}{lccccc}
\hline & \multicolumn{5}{c}{ Time $(\mathrm{min})$} \\
\cline { 2 - 6 } & 0 & 15 & 30 & 45 & 60 \\
\hline Plasma ECLIA-ACTH $(\mathrm{pg} / \mathrm{mL})$ & 75.8 & 117.1 & 108.1 & 88.3 & 89.5 \\
Serum cortisol $(\mu \mathrm{g} / \mathrm{dL})$ & 7.9 & 9.5 & 9.2 & 9.4 & 9.2 \\
Serum $\mathrm{GH}(\mathrm{ng} / \mathrm{mL})$ & 1.5 & 33.8 & 31.2 & 21.2 & 13.8 \\
Serum prolactin $(\mathrm{ng} / \mathrm{mL})$ & 12.1 & 18.3 & 17.8 & 16.8 & 16.4 \\
\hline GHRP-2 $(100 \mu \mathrm{g})$ was intravenously administered in the morning $(8: 00 \mathrm{AM})$. The test was \\
conducted after cessation of hydrocortisone replacement therapy (5 mg/day) for a day.
\end{tabular}

normal under the same hydrocortisone replacement regimen, but she still exhibited cortisol and DHEA-S deficiency (Table $2 \mathrm{H}$ ). These findings were not explained by a recovery process from glucocorticoid-induced AI, but rather indicated a diagnosis of secondary AI accompanied by bioinactive ACTH. Because a dynamic test performed in a euthyroid state confirmed normal secretion of pituitary hormones, with the exception of the inconsistency between the high plasma ACTH levels and no cortisol response (Table 2G), our patient likely developed IAD with a substantial amount of biochemically measurable ACTH with little steroidogenic bioactivity.
Primary AI is characterized by a deficiency of all adrenal hormones, including the mineralocorticoids. As our patient had normal serum aldosterone levels throughout her clinical course (Fig. 1), it is unlikely that our patient had primary AI (3). In addition, the adequate cortisol response to an exogenous ACTH load (Table 2C) indicated that the adrenal gland ACTH receptors were intact.

Table 4 shows a summary of previously reported patients who exhibited concurrent IAD and Graves' disease. These cases include adults of both sexes who were diagnosed nearly simultaneously with both IAD and Graves' disease that were manifested as fatigue and appetite loss, with or 
F. Data from the CRH/GRF/TRH/LHRH stimulation test performed in May 2013

\begin{tabular}{|c|c|c|c|c|c|c|}
\hline & \multicolumn{6}{|c|}{ Time (min) } \\
\hline & 0 & 15 & 30 & 60 & 90 & 120 \\
\hline Plasma ECLIA-ACTH (pg/mL) & 65.6 & 78.2 & 84.9 & 104.0 & 96.3 & 95.1 \\
\hline Serum cortisol $(\mu \mathrm{g} / \mathrm{dL})$ & 6.1 & 5.5 & 5.7 & 6.3 & 6.2 & 6.2 \\
\hline Serum TSH $(\mu \mathrm{U} / \mathrm{mL})$ & 2.91 & 24.80 & 35.82 & 30.41 & 22.25 & 16.76 \\
\hline Serum GH $(\mathrm{ng} / \mathrm{mL})$ & 1.9 & 9.8 & 7.4 & 3.5 & 1.9 & 1.2 \\
\hline Serum prolactin $(\mathrm{ng} / \mathrm{mL})$ & 9.9 & 42.7 & 48.0 & 32.5 & 23.6 & 18.9 \\
\hline Serum LH $(\mathrm{mIU} / \mathrm{mL})$ & 11.4 & 16.4 & 20.6 & 25.1 & 25.5 & 24.3 \\
\hline Serum FSH $(\mathrm{mIU} / \mathrm{mL})$ & 28.3 & 29.2 & 30.4 & 31.1 & 31.2 & 34.6 \\
\hline
\end{tabular}

The following were intravenously administered in the morning (8:00 AM): CRH $100 \mu \mathrm{g}$, GRF $100 \mu \mathrm{g}$, TRH 500 $\mu \mathrm{g}$, and LHRH 100 $\mu \mathrm{g}$. The test was conducted after cessation of hydrocortisone replacement therapy $(10 \mathrm{mg} /$ day $)$ for half a day. The patient was clinically euthyroid, under treatment for Graves' disease with oral thiamazole $10 \mathrm{mg} / \mathrm{day}$.

\title{
G. CRH/GRF/TRH/LHRH stimulation test in August 2013
}

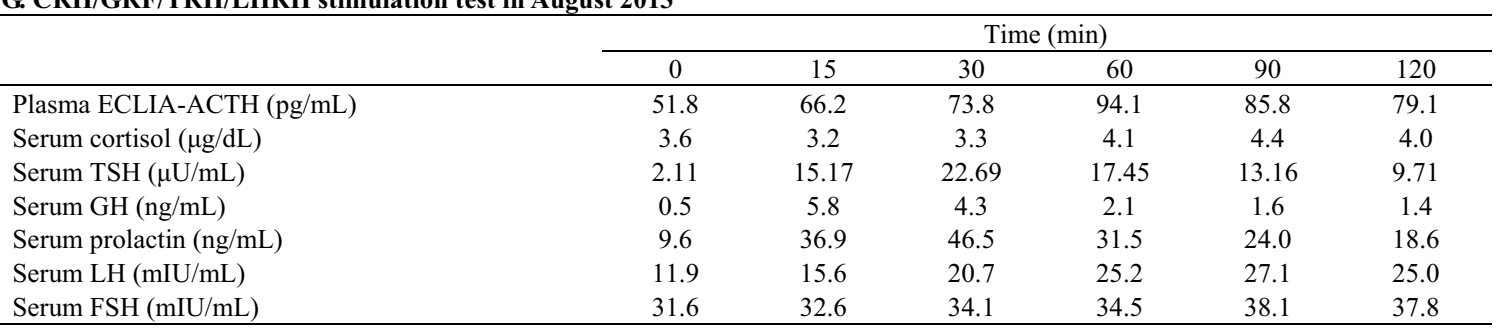

The following were intravenously administered in the morning (8:00 AM): CRH $100 \mu \mathrm{g}$, GRF $100 \mu \mathrm{g}$, TRH $500 \mu \mathrm{g}$, and LHRH $100 \mu \mathrm{g}$. The test was conducted after cessation of hydrocortisone replacement therapy $(10 \mathrm{mg} /$ day $)$ for half a day. The patient was clinically euthyroid, under treatment for Graves' disease with oral thiamazole $7.5 \mathrm{mg} / \mathrm{day}$.

\section{H. CRH/GRF/TRH/LHRH stimulation test in February 2015}

\begin{tabular}{|c|c|c|c|c|c|c|}
\hline & \multicolumn{6}{|c|}{ Time (min) } \\
\hline & 0 & 15 & 30 & 60 & 90 & 120 \\
\hline Plasma ECLIA-ACTH (pg/mL) & 31.6 & 44.5 & 44.6 & 65.2 & 60.1 & 52.7 \\
\hline Plasma $\gamma 3-\mathrm{MSH}(\mathrm{pg} / \mathrm{mL})$ & $<30.0$ & $<30.0$ & $<30.0$ & $<30.0$ & $<30.0$ & $<30.0$ \\
\hline Serum cortisol $(\mu \mathrm{g} / \mathrm{dL})$ & 3.4 & 3.2 & 2.9 & 3.3 & 3.3 & 3.2 \\
\hline Serum TSH $(\mu \mathrm{U} / \mathrm{mL})$ & 6.02 & 54.34 & 73.07 & 55.44 & 39.87 & 26.94 \\
\hline Serum GH $(\mathrm{ng} / \mathrm{mL})$ & 0.74 & 10.10 & 7.85 & 4.87 & 2.13 & 0.97 \\
\hline Serum prolactin $(\mathrm{ng} / \mathrm{mL})$ & 10.6 & 50.1 & 57.5 & 38.7 & 26.4 & 19.4 \\
\hline Serum LH (mIU/mL) & 8.8 & 12.0 & 16.3 & 19.6 & 20.8 & 18.7 \\
\hline Serum FSH (mIU/mL) & 18.3 & 19.5 & 19.1 & 20.2 & 20.7 & 20.4 \\
\hline
\end{tabular}

The following were intravenously administered in the morning (8:00 AM): CRH $100 \mu \mathrm{g}$, GRF $100 \mu \mathrm{g}$, TRH 500 $\mu \mathrm{g}$, and LHRH, 100 $\mu \mathrm{g}$. The test was conducted after cessation of hydrocortisone replacement therapy $(10 \mathrm{mg} /$ day $)$ for half a day. The patient had primary subclinical hypothyroidism, under treatment for Graves' disease with oral thiamazole $10 \mathrm{mg} /$ day.

\begin{abstract}
ACTH: adrenocorticotropic hormone, CRH: human corticotropin-releasing hormone, ECLIA: electro-chemiluminescence immunoassay, FSH: follicle-stimulating hormone, GH: growth hormone, GHRP: growth hormone-releasing peptide, GRF: growth hormone-releasing factor, LH: luteinizing hormone, LHRH: gonadotropin-releasing hormone, MSH: melanocyte-stimulating hormone, TRH: thyrotropin-releasing hormone, TSH: thyroid-stimulating hormone
\end{abstract}

without hypoglycemic attack. The patients exhibited various plasma ACTH levels measured by different assays, and some patients had empty sella turcica.

At the time of IAD development, our patient had a high plasma ACTH level, as measured using various bioassays, including ECLIA, IRMA, FEIA, and ICT-EIA I (18-22) (Table 3). A gel filtration analysis with conventional ACTHRIA did not detect "big ACTH" in the plasma, but detected peptides that were roughly the same size as authentic ACTH 1-39 (Fig. 4). These findings were similar to those of previously reported cases of secondary AI in which high plasma ACTH levels, but not "big ACTH", were found using different assays (6-9). In the present case, the absence of "big ACTH" was confirmed by the finding that $\gamma 3$-MSH was undetectable (23) (Table 3). Several studies have shown that conventional ACTH-RIA employing polyclonal antibodies can detect not only authentic ACTH 1-39, pro-ACTH, and POMC, but also ACTH fragments with the loss of several
N-terminal amino acids, such as ACTH 7-39 (29). A recent study also suggested that the ACTH-ECLIA and FEIA can identify ACTH fragments with complete C-terminal regions, even when several N-terminal amino acids are absent (30). However, the biological activity of the ACTH molecule is dependent on the first $24 \mathrm{~N}$-terminal amino acids (ACTH 124 ), but the shorter peptides of less than 20 amino acids are ineffective $(1,2,31)$. Thus, our patient might have exhibited ACTH fragments with a deficit of several N-terminal amino acids in the plasma.

An empty sella turcica is defined as an intrasellar herniation of the suprasellar subarachnoid space with compression of the pituitary gland (32). It can be caused by pituitary surgery or radiation, but many cases are of unknown etiology. There are some reported cases of an empty sella turcica in IAD patients with or without Graves' disease $(14,16,33)$. Our patient was found to have an empty sella turcica (Fig. 2) without any verifiable causes, concomitant with 

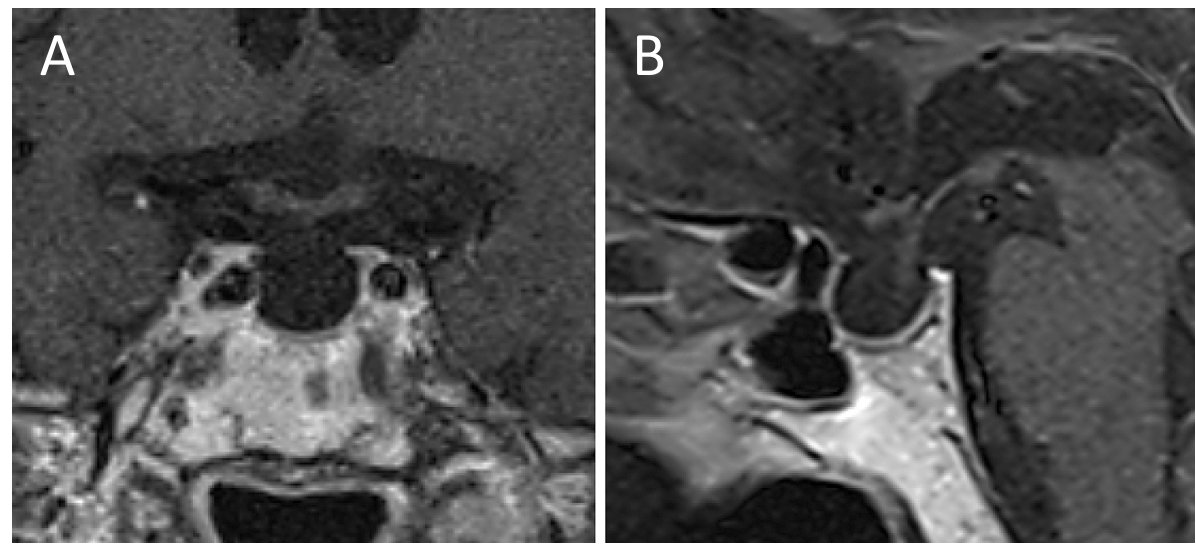

Figure 2. Magnetic resonance imaging of the pituitary gland (February 2013). Gadolinium-enhanced T1-weighted magnetic resonance imaging of the brain (A: coronal plane; B: sagittal plane) showed an enlarged sella turcica filled with cerebrospinal fluid, indicating that the sella was empty. No abnormalities were evident in the hypothalamus or hypophyseal stalk.

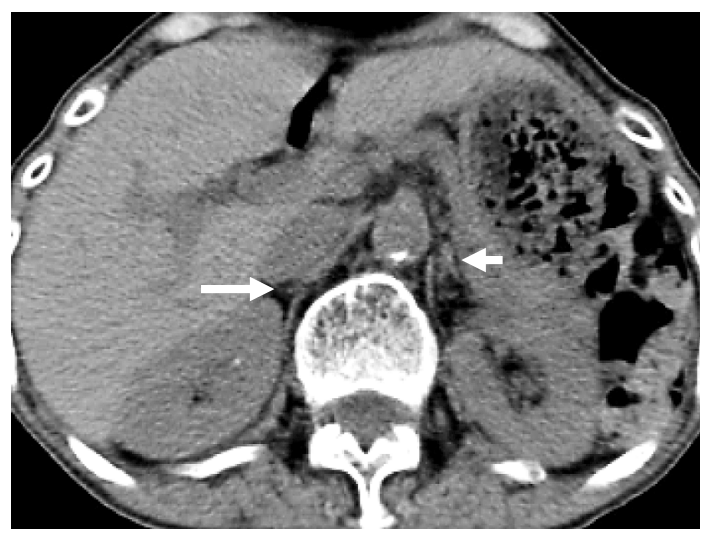

Figure 3. Computed tomography of the adrenal glands (February 2013). A plain computed tomography scan of the abdomen revealed no abnormality in either the right or left adrenal gland (long and short arrows, respectively).

Graves' disease, while an etiological relationship between the patient's empty sella turcica and IAD remained uncertain.

Polyglandular autoimmune syndrome (PGAS) type 3 is a group of endocrine or nonendocrine organ-specific autoimmune disorders, including autoimmune thyroid diseases, for which genetic factors are involved in the pathogenesis (34). Our patient had an HLA-DRB1*09:01- DQB1*03:03-DQA1 *03:02 haplotype, which increases the susceptibility of Japanese individuals to PGAS type 3 (35). Therefore, although our patient tested negative for the anti-pituitary cell antibody, the presence of Graves' disease suggested an autoimmune etiology for her IAD.

The typical symptoms of thyrotoxicosis include fatigue, exertional dyspnea, hyperactivity, and body weight loss with or without an increased appetite; however, older patients may sometimes present with lethargy and anorexia (36). Our patient did not experience any improvement in her fatigue, lethargy, or anorexia during the 1-week treatment regimen with supraphysiological doses of oral prednisolone therapy for her bronchial asthma and thereafter developed severe hypoglycemia accompanied by mild AI after completion of the prednisolone therapy. Therefore, she did not have clinical AI prior to prednisolone therapy, and her fatigue, lethargy, and anorexia were likely attributable to Graves' hyperthyroidism. On the other hand, 1 week of supraphysiological prednisolone administration seldom causes glucocorticoid-induced AI (37). However, both hyperthyroidism and the prior use of physiological doses of corticosteroids, irrespective of the route of administration, may increase susceptibility to glucocorticoid-induced AI by increasing the rate of glucocorticoid metabolism (38) or by potentially exerting antisecretory effects on CRH and ACTH $(1,2)$. Additionally, malnutrition caused by anorexia per se can cause hypoglycemia (39). Taken together, a combination of previously inhaled ciclesonide, the presence of thyrotoxicosis and anorexia, and the taking of transient supraphysiological doses of prednisolone, might have induced severe hypoglycemia accompanied by mild glucocorticoid-induced AI in the present case (Table 1).

Our patient had an adequate plasma ACTH to serum cortisol ratio of approximately $4(6,40)$ during the hypoglycemic coma, and the ACTH to cortisol ratio rapidly increased to $>10$ within a few days (Table 1, 2A). On the other hand, abnormal processing of POMC in the anterior pituitary can occur at both the translational and the (enzymatic) posttranslational levels (41). These findings suggest that, although the precise mechanism is unknown, our elderly patient developed IAD, following mild glucocorticoid-induced AI, and synthesized a bioinactive ACTH that might have been aberrantly (enzymatically) processed after translation.

GHRP-2, a synthetic agonist of ghrelin, is a potent growth hormone secretagogue and also stimulates the secretion of ACTH and cortisol in humans (42). The GHRP-2 test has been shown to be a diagnostic tool for secondary AI $(43,44)$. At the time of IAD development, our patient exhibited a delayed (and slight) ACTH release to exogenous $\mathrm{CRH}$ (Table 2D), and in contrast, a rather rapid ACTH re- 
Table 3. Basal Levels of Plasma ACTH Measured Using Different Bioassays, and the Levels of Plasma $\gamma 3$-MSH.

\begin{tabular}{lccccc}
\hline & March & August & February & \multirow{2}{*}{ Unit } & \multirow{2}{*}{ Reference range } \\
& 2013 & 2013 & 2015 & & \\
\hline ECLIA-ACTH & 77.2 & 51.8 & 31.6 & $\mathrm{pg} / \mathrm{mL}$ & $7.2-63.3$ \\
FEIA-ACTH & 64.1 & 44.5 & 28.0 & $\mathrm{pg} / \mathrm{mL}$ & $7.7-63.1$ \\
IRMA-ACTH & 59.5 & 42.5 & 25.9 & $\mathrm{pg} / \mathrm{mL}$ & $7.4-55.7$ \\
ICT-EIA I-ACTH & 81.1 & 42.6 & 21.6 & $\mathrm{pg} / \mathrm{mL}$ & $4.0-45.0$ \\
RIA- $\gamma 3-$ MSH & $<30.0$ & $<30.0$ & $<30.0$ & $\mathrm{pg} / \mathrm{mL}$ & $<30.0$ \\
\hline
\end{tabular}

Blood samples were taken in the morning (8:00 AM), after cessation of hydrocortisone replacement for more than half a day, in March 2013 (day 21 after admission); in August 2013; and in February 2015, as shown in Table 2D, G, and H, respectively.

ACTH: adrenocorticotropic hormone, ECLIA: electro-chemiluminescence immunoassay, FEIA: fluorescence enzyme immunoassay, ICT-EIA: immune complex transfer enzyme immunoassay, IRMA: immunoradiometric assay, MSH: melanocyte-stimulating hormone, RIA: radioimmunoassay

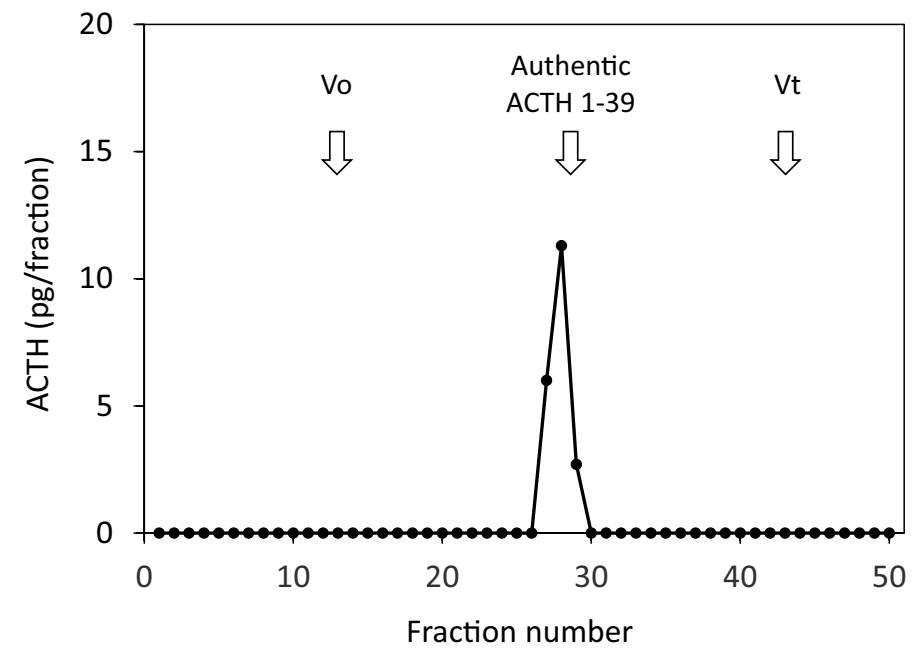

Figure 4. The gel filtration profile of the patient's plasma (March 2013). The arrows indicate the elution positions of authentic adrenocorticotropic hormone (ACTH) 1-39, void volume (Vo), and total volume $(\mathrm{Vt})$. The numbers on the $\mathrm{x}$ axis represent the fraction numbers.

Table 4. Summary of Reported Patients who Presented with Concomitant Graves' Disease and Isolated Adrenocorticotropin Deficiency.

\begin{tabular}{|c|c|c|c|c|c|c|c|c|c|c|c|c|c|}
\hline \multirow[b]{2}{*}{ Case } & \multirow[b]{2}{*}{ Sex } & \multirow[b]{2}{*}{ Major symptoms } & \multicolumn{4}{|c|}{ Graves' disease } & \multicolumn{6}{|c|}{ Isolated adrenocorticotropin deficiency } & \multirow[b]{2}{*}{ Ref. } \\
\hline & & & $\begin{array}{c}\text { Age at } \\
\text { diagnosis } \\
\text { (years) }\end{array}$ & $\begin{array}{c}\text { TRAb } \\
\text { or } \\
\text { TSAb }\end{array}$ & $\begin{array}{c}\text { Palpable } \\
\text { struma }\end{array}$ & $\begin{array}{l}\text { Exophtha } \\
\text { lmos }\end{array}$ & $\begin{array}{c}\text { Age at } \\
\text { diagnosis } \\
\text { (years) }\end{array}$ & $\begin{array}{c}\text { Basal serum } \\
\text { cortisol levels } \\
(\mu \mathrm{g} / \mathrm{mL})^{*}\end{array}$ & $\begin{array}{c}\text { Basal plasma } \\
\text { ACTH levels } \\
(\mathrm{pg} / \mathrm{mL})^{*}\end{array}$ & $\begin{array}{c}\text { Pituitary } \\
\text { autoantibodies }\end{array}$ & $\begin{array}{l}\text { MRI findings of } \\
\text { pituitary gland }\end{array}$ & $\begin{array}{l}\text { Complicating } \\
\text { disorders }\end{array}$ & \\
\hline 1 & Female & $\begin{array}{c}\text { Fatigue, appetite } \\
\text { loss, palpitation, } \\
\text { hypoglycemia }\end{array}$ & 43 & Positive & $(+)$ & $(-)$ & 43 & Undetectable & Undetectable & Negative & Empty sella & None & 14 \\
\hline 2 & Female & $\begin{array}{c}\text { Fatigue, } \\
\text { appetite loss }\end{array}$ & 47 & Positive & $(+)$ & $(+)$ & 47 & 4.1 & $<5$ & Negative & N.A. & $\begin{array}{l}\text { Systemic lupus } \\
\text { erythematosus }\end{array}$ & 15 \\
\hline 3 & Male & $\begin{array}{c}\text { Fatigue, } \\
\text { body weight loss }\end{array}$ & 60 & Positive & $(-)$ & $(-)$ & 60 & 0.9 & 6.8 & Negative & Empty sella & None & 16 \\
\hline 4 & Male & $\begin{array}{l}\text { Appetite loss, } \\
\text { palpitation }\end{array}$ & 73 & Positive & $(-)$ & $(-)$ & 73 & 3.9 & 9.0 & N.A. & No abnormalities & None & 17 \\
\hline 5 & Female & $\begin{array}{c}\text { Fatigue, lethargy, } \\
\text { appetite loss, } \\
\text { hypoglycemia }\end{array}$ & 73 & Positive & $(+)$ & $(-)$ & 73 & 5.0 & 87.3 & Negative & Empty sella & $\begin{array}{c}\text { Bronchial asthma } \\
\text { hypertension, } \\
\text { T2DM }\end{array}$ & $\begin{array}{l}\text { Present } \\
\text { case }\end{array}$ \\
\hline
\end{tabular}

*Basal cortisol and adrenocorticotropic hormone (ACTH) levels were measured at the time of diagnosis of isolated adrenocorticotropin deficiency by different bioassays (6) from case to case.

The case 3 patient underwent treatment with oral thiamazole and cortisone acetate for hyperthyroidism and adrenal insufficiency from the age of 47 years until the diagnoses of isolated adrenocorticotropin deficiency and Graves' disease.

MRI: magnetic resonance imaging, N.A.: not available,TRAb: thyroid-stimulating hormone receptor antibody, TSAb: thyroid stimulating antibody, T2DM: type 2 diabetes mellitus 
lease was observed after GHRP-2 loading (Table 2E), neither of which triggered a significant cortisol response. These findings suggest that GHRP-2 may have stimulated the impaired corticotroph cells via pathways other than the CRH receptor, under conditions of almost full endogenous CRH stimulation.

In conclusion, our elderly patient with Graves' hyperthyroidism and anorexia developed hypoglycemia accompanied by mild glucocorticoid-induced AI after a supraphysiological dose of oral prednisolone therapy for bronchial asthma. Shortly thereafter, she developed IAD with high plasma ACTH measurements, for which bioinactive ACTH that was not "big ACTH," such as ACTH fragments with a deficit of several N-terminal amino acids, was likely responsible. The present case suggests that IAD may develop in association with glucocorticoid-induced AI. In addition, IAD should therefore be considered was an unusual complicating disorder in patients with Graves' disease, especially in older adults.

The authors state that they have no Conflict of Interest (COI).

\section{Acknowledgement}

We thank the medical laboratory technicians of Nagaoka Red Cross Hospital for their valuable technical support.

\section{References}

1. Margioris AN, Tsatsanis C. ACTH action on the adrenal. In: Endotext [Internet]. [cited 2015 Sep. 21]. De Groot LJ, Beck-Peccoz P, Chrousos G, et al, Eds. MDText.com, Inc, South Dartmouth, MA, 2011. Available from: http://www.ncbi.nlm.nih.gov/books/NB K279118/

2. Oki Y. Adrenocorticotropic hormone. Naibunpitsu Tonyobyo Taishanaika (Endocrinology, Diabetology \& Metabolism) 36: 134-139, 2013 (in Japanese).

3. Charmandari E, Nicolaides NC, Chrousos GP. Adrenal insufficiency. Lancet 383: 2152-2167, 2014.

4. Krasner AS. Glucocorticoid-induced adrenal insufficiency. JAMA 282: 671-676, 1999.

5. LaRochelle GE Jr, LaRochelle AG, Ratner RE, Borenstein DG. Recovery of the hypothalamic-pituitary-adrenal (HPA) axis in patients with rheumatic diseases receiving low-dose prednisone. Am J Med 95: 258-264, 1993.

6. Oki Y. Tests for pituitary adrenal system: the interpretation of measured values of adrenocorticotropic hormone and cortisol. Nihon Rinsho Kensa Jidoka Gakkai Kaishi (Japanese Journal of Clinical Laboratory Automation) 36: 449, 2011 (in Japanese).

7. Sakai K, Horiba N, Sakai Y, Suda T. A case of secondary adrenal insufficiency with high plasma adrenocorticotropic hormone levels. ACTH RELATED PEPTIDES 8: 267-271, 1997 (in Japanese).

8. Ozawa M, Oki Y, Matsushita F, Nakamura H. A case of secondary adrenal insufficiency associated with low bioactive form of adrenocorticotropic hormone. Horumon To Rinsho (Clinical Endocrinology) 48: 59-63, 2000 (in Japanese).

9. Nakamura J, Ishii S, Tamura $\mathrm{H}$, et al. A case of adrenal insufficiency associated with low bioactivity of adrenocorticotropic hormone. Nihon Naibunpitsu Gakkai Zasshi (Folia Endocrinologica Japonica) 79: 99-102, 2003 (in Japanese).

10. Yamakita N, Murai T, Oki Y, et al. Adrenal insufficiency after incomplete resection of pituitary macrocorticotropinoma of Cushing's disease: role of high molecular weight ACTH. Endocr J 48:
43-51, 2001.

11. Ogawa N, Yamauchi M, Suzuki T, et al. A case of thyroid crisis associated with adrenal insufficiency caused by inactive form of adrenocorticotropic hormone. Nihon Naibunpitsu Gakkai Zasshi (Folia Endocrinologica Japonica) 84: 84-86, 2008 (in Japanese).

12. Andrioli M, Pecori Giraldi F, Cavagnini F. Isolated corticotrophin deficiency. Pituitary 9: 289-295, 2006.

13. Kasperlik-Załuska AA, Czarnocka B, Czech W. Autoimmunity as the most frequent cause of idiopathic secondary adrenal insufficiency: report of 111 cases. Autoimmunity 36: 155-159, 2003.

14. Muto N, Ito Y, Komaki T, Yamakita Y, Ikeda Y. A case of the isolated ACTH deficiency with Graves' disease and empty sella. Horumon To Rinsho (Clinical Endocrinology) 44: 45-49, 1996 (in Japanese).

15. Matsuo T, Takamatsu J, Makino S, et al. A case of Graves' disease with ACTH deficiency and with aggravation of SLE. Horumon To Rinsho (Clinical Endocrinology) 48: 92-96, 2000 (in Japanese).

16. Miyauchi S, Yamashita Y, Matsuura B, Onji M. Isolated ACTH deficiency with Graves' disease: a case report. Endocr J 51: 115119, 2004.

17. Yusawa M, Yoshioka T, Saito T, et al. A case of isolated ACTH deficiency with relapsing Graves' disease. Rinsho Taieki (Proceedings of the Congress on Electrolyte Metabolism) 34: 49-53, 2007 (in Japanese).

18. Abe M, Araki S, Tawaragi M, et al. Fundamental evaluation of ACTH measurement using automated electrochemiluminescenceimmunoassay system, ECLusys ${ }^{\circledR}$ 2010. Igaku To Yakugaku (Japanese Journal of Medicine and Pharmaceutical Science) 57: 239244, 2007 (in Japanese).

19. Katakami H. Adrenocorticotropic hormone. In: Rinsho Kensa Gaido. Mitsuhashi T, Medical Practice Editorial Committee, Eds. Bunkodo, Tokyo, 2015: 357-369 (in Japanese).

20. Nishi I, Takeoka K, Ichihara K, Amino N, Miyai K. Fundamental and clinical evaluation of ACTH IRMA Kit "MITSUBISHIYUKA”. Igaku To Yakugaku (Jpn J Med Pharm Sci.) 24: 657-664, 1990 (in Japanese).

21. Herai T, Kawasaki R, Endo S, Takeshita A, Yoneyama A. Evaluation of an adrenocorticotropic hormone measurement reagent, ST AIA-PACK ACTH, and comparison of its reactivity with highmolecular-weight ACTH with other assays. Nihon Rinsho Kensa Jidoka Gakkai Kaishi (Japanese Journal of Clinical Laboratory Automation) 37: 21-28, 2012 (in Japanese).

22. Katakami H, Hashida S, Nasu K, Matsuno A. Development and clinical application of a novel ultrasensitive assay for human ACTH1-39. ACTH RELATED PEPTIDES 19: 40-43, 2008 (in Japanese).

23. Katakami H, Hashida S, Matsuno A, Yamada S. Development and clinical application of measuring system for "big ACTH" (1): Development of $\gamma 3$-MSH RIA. ACTH RELATED PEPTIDES 20: $27-$ 30, 2009 (in Japanese).

24. Oki K, Yamane K, Oda Y, et al. Combined acromegaly and subclinical Cushing disease related to high-molecular-weight adrenocorticotropic hormone. J Neurosurg 110: 369-373, 2009.

25. Committee on the Standardization of Diabetes Mellitus-Related Laboratory Testing of Japan Diabetes Society. International clinical harmonization of glycated hemoglobin in Japan: From Japan Diabetes Society to National Glycohemoglobin Standardization Program values. J Diabetes Invest 3: 39-40, 2012.

26. Menconi F, Marcocci C, Marinò M. Diagnosis and classification of Graves' disease. Autoimmun Rev 13: 398-402, 2014.

27. Lipworth BJ, Kaliner MA, LaForce CF, et al. Effect of ciclesonide and fluticasone on hypothalamic-pituitary-adrenal axis function in adults with mild-to-moderate persistent asthma. Ann Allergy Asthma Immunol 94: 465-472, 2005.

28. Fischli S, Jenni S, Allemann S, et al. Dehydroepiandrosterone sul- 
fate in the assessment of the hypothalamic-pituitary-adrenal axis. J Clin Endocrinol Metab 93: 539-542, 2008.

29. Oki Y, Yamashita M, Hayashi C, Ino K, Nakamura H. Examination of the error among different measurements of plasma adrenocorticotropic hormone: the third report. ACTH RELATED PEPTIDES 16: 97-101, 2005 (in Japanese).

30. Oki Y. Pitfall of the interpretation of measured values of plasma adrenocorticotropic hormone. ACTH RELATED PEPTIDES 22: 910, 2011 (in Japanese).

31. Vinson GP, Whitehouse BJ, Bateman A, Dell A, Laird SM. The actions of N-terminal fragments of corticotrophin on steroidogenesis in dispersed rat adrenal cells in vitro. J Endocrinol 109: 275278, 1986.

32. Naing S, Frohman LA. The empty sella. Pediatr Endocrinol Rev 4: 335-342, 2007

33. Gulcan E, Gulcan A, Taser F, Korkmaz U, Erbilen E. May primary empty sella turcica be a cause of isolated ACTH deficiency? A case report and the review of related literature. Neuro Endocrinol Lett 28: 745-748, 2007.

34. Cutolo M. Autoimmune polyendocrine syndromes. Autoimmun Rev 13: 85-89, 2014.

35. Hashimoto K, Maruyama H, Nishiyama M, et al. Susceptibility alleles and haplotypes of human leukocyte antigen DRB1, DQA1, and DQB1 in autoimmune polyglandular syndrome type III in Japanese population. Horm Res 64: 253-260, 2005.

36. Samuels MH, Franklyn JA. Hyperthyroidism in aging. In: Endotext [Internet]. DeGroot LJ, Beck-Peccoz P, Chrousos G, et al, Eds. MDText.com, Inc, South Dartmouth, MA, 2015. Available from: http://www.ncbi.nlm.nih.gov/books/NBK278986/

37. Carella MJ, Srivastava LS, Gossain VV, Rovner DR.
Hypothalamic-pituitary-adrenal function one week after a short burst of steroid therapy. J Clin Endocrinol Metab 76: 1188-1191, 1993.

38. Agbaht K, Gullu S. Adrenocortical reserves in hyperthyroidism. Endocrine 45: 136-143, 2014.

39. Mattingly D, Bhanji S. Hypoglycaemia and anorexia nervosa. J R Soc Med 88: 191-195, 1995.

40. Lee MK, Vasikaran S, Doery JC, Wijeratne N, Prentice D. Cortisol: ACTH ratio to test for primary hypoadrenalism: a pilot study. Postgrad Med J 89: 617-620, 2013.

41. Imura H. ACTH and related peptides: molecular biology, biochemistry and regulation of secretion. Clin Endocrinol Metab 14: 845866, 1985.

42. Arvat E, di Vito L, Maccagno B, et al. Effects of GHRP-2 and hexarelin, two synthetic GH-releasing peptides, on GH, prolactin, ACTH and cortisol levels in man. Comparison with the effects of GHRH, TRH and hCRH. Peptides 18: 885-891, 1997.

43. Kageyama K, Nigawara T, Sakihara S, et al. Diagnostic usefulness of the growth hormone-releasing peptide-2 test as a substitute for the insulin tolerance test in hypopituitarism. Endocr J 55: 777-783, 2008.

44. Ohara N, Kojima N, Sato T, et al. Type 1 diabetes mellitus and isolated adrenocorticotropin deficiency manifested by parkinsonism: a case report and literature review. Intern Med 54: 2629$2635,2015$.

The Internal Medicine is an Open Access article distributed under the Creative Commons Attribution-NonCommercial-NoDerivatives 4.0 International License. To view the details of this license, please visit (https://creativecommons.org/licenses/ by-nc-nd/4.0/).

(C) 2016 The Japanese Society of Internal Medicine http://www.naika.or.jp/imonline/index.html 